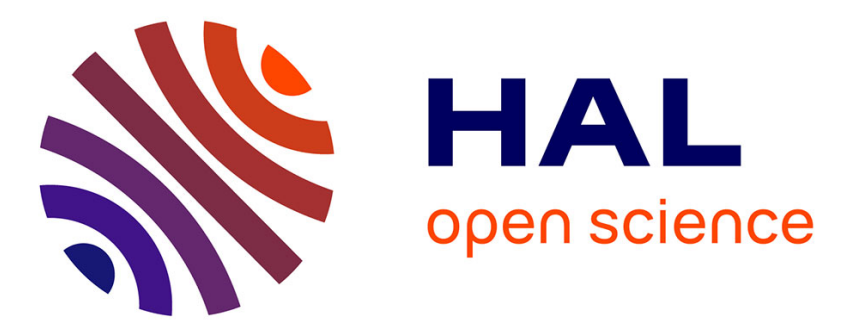

\title{
Low-Melting Metal Resistance to Plastic Strain in Shock-Compressed State
}

\author{
Yu. Batikov, B. Glushak, S. Novikov, N. Fishman
}

\section{To cite this version:}

Yu. Batikov, B. Glushak, S. Novikov, N. Fishman. Low-Melting Metal Resistance to Plastic Strain in Shock-Compressed State. Journal de Physique IV Proceedings, 1997, 07 (C3), pp.C3-477-C3-480. 10.1051/jp4:1997382 . jpa-00255539

\section{HAL Id: jpa-00255539 https://hal.science/jpa-00255539}

Submitted on 1 Jan 1997

HAL is a multi-disciplinary open access archive for the deposit and dissemination of scientific research documents, whether they are published or not. The documents may come from teaching and research institutions in France or abroad, or from public or private research centers.
L'archive ouverte pluridisciplinaire HAL, est destinée au dépôt et à la diffusion de documents scientifiques de niveau recherche, publiés ou non, émanant des établissements d'enseignement et de recherche français ou étrangers, des laboratoires publics ou privés. 


\title{
Low-Melting Metal Resistance to Plastic Strain in Shock-Compressed State
}

\author{
Yu.V. Batikov, B.L. Glushak, S.A. Novikov* and N.D. Fishman** \\ * Federal Nuclear Center of Russia, VNIIIEF, Arzamas 16, 607190 Mira pr. 37, Nizhni Novgorog region, \\ Russia \\ ** Materials Division, Office of Naval Research, 800 N. Quincy St., VA 22217 Arlington, U.S.A.
}

\begin{abstract}
The measuremental results are presented for the main stresses, $\sigma_{x}$ and $\sigma_{y}$, behind the plane stationary shock wave front in the low-melting metals $(\mathrm{Mg}, \mathrm{Cd}, \mathrm{Sn}, \mathrm{Zn}, \mathrm{Bi}$ ). In every test the piesoresistive gauges were employed for the measurements, placed in two mutually perpendicular planes of a sample. The gauge measuring element is a linear piece of the manganine wire of $0.05 \mathrm{~mm}$ in diameter and $10 \mathrm{~mm}$ long. The total gauge thickness with polymer insulation was $0.23 \mathrm{~mm}$ at low stresses and $0.53 \mathrm{~mm}$ at high ones behind the shock wave front. Stationary shock waves of duration about $\sim 1 \mu$ s entered into the sample from the screen where the shock wave propagates being generated by a detonation wave incident along the normal.

The measured values correctness for the main stresses, $\sigma_{x}$ and $\sigma_{y}$, is supported by the special tests with paraffin, steel (elastic and plastic deformation regions), ceramics (elastic deformation regions) and vanadium.

For the low-melting metals investigation in the normal stresses range, $\sigma_{x}=4-25$ GPA, the strong strengthening was recorded at the high-speed deformation by the shock waves. The dependence of dynamic ultimate yield, $Y_{B}=\sigma_{x}-\sigma_{y}$ on $\sigma_{x}$ approaches a linear one the range investigation.

Resume: Les résultats des mesures des contraintes principales $\sigma_{x}$ et $\sigma_{y}$ ayant lieu derrière le front de l'onde de choc plate stationnaire dans les métaux fusibles $(\mathrm{Mg}, \mathrm{Cd}, \mathrm{Sn}, \mathrm{Zn}, \mathrm{Bi})$ sont présentés. Les mesures sont été réalisées par les capteurs piézorésistants disposés dans deux plans d'échantillon réciproquement perpendiculaires. Les ondes de choc stationnaires de durée $\sim 1 \mu$ s ont été introduites dans l'échantillon de l'écran dans lequel l'onde de choc produite par l'onde de détonation normale se propagait.

Le durcissement fort a été enregistré pour les métaux fusibles examinés dans la gamme des contraintes normales $\sigma_{x}=4-25$ GPa à la déformation ultra-rapide dans les ondes de choc. Dans la gamme examinée la relation entre la limite élastique dynamique $Y_{\mathrm{y}}=\sigma_{\mathrm{x}}-\sigma_{\mathrm{y}}$ et $\sigma_{\mathrm{x}}$ ressemblait beaucoup à la relation lineaire.
\end{abstract}

Investigations of resistance of materials, compressed by stationary shock wave, reveal a complicated character of manifestation of reological properties. Different methods, such as the method of overtaking unloading [1], "self-consistent" method [2], measurement of unloading elastic wave amplitude [3], etc. are employed to obtain experimental data on reological properties of shockcompressed substances. The special place is given to the method of direct measurement of the primary stresses $\left(\sigma_{x}, \sigma_{y}\right)$ in one experiment in two mutually perpendicular sections of the sample under study, where shock wave (SW) propagates in the $x$ axis direction $[4,5]$.

Measurements of $\sigma_{x}$ and $\sigma_{y}$ allow to determine the value $Y_{g}=\sigma_{x}-\sigma_{y}$ without any additional assumptions and calculations of the medium flow, if assuming that according to $[6,7]$ the model of hardened elasto-plastic medium with effective dynamic yield strength $Y_{\mathrm{g}}$ (DYS) is true for metals behind the front of SW with amplitude more than $\sim \mathrm{GPa}$ and, correspondingly, strains rates higher than $10^{-5} \mathrm{~s}$.

In this work the DYS value of low-melting metals $(\mathrm{Mg}, \mathrm{Bi}, \mathrm{Cd}, \mathrm{Zn}, \mathrm{Sn})$ is determined in the range of primary stress change $\sigma_{x}=2.5 \ldots 20 \mathrm{GPa}$ by primary stresses method (PSM). Scheme of the experiments is described in detail in $[8,9,10]$. The piesoresistive $\Pi$-shaped gauges, which had been 
manufactured from manganin wire with diameter of $0.05 \mathrm{~mm}$ and placed in thin isolating medium (lavsan, fluoroplastic), were located in cuts in a sample of the metal under study. Total thickness of the gauge, including layers of additional isolation, was $0.25 \ldots 0.53 \mathrm{~mm}$, and length of the gauge sensor was $10 \mathrm{~mm}$. Characteristic oscillograms of recorded signals, caused by sensors (fig. 1 ) show change for the stationary regime.
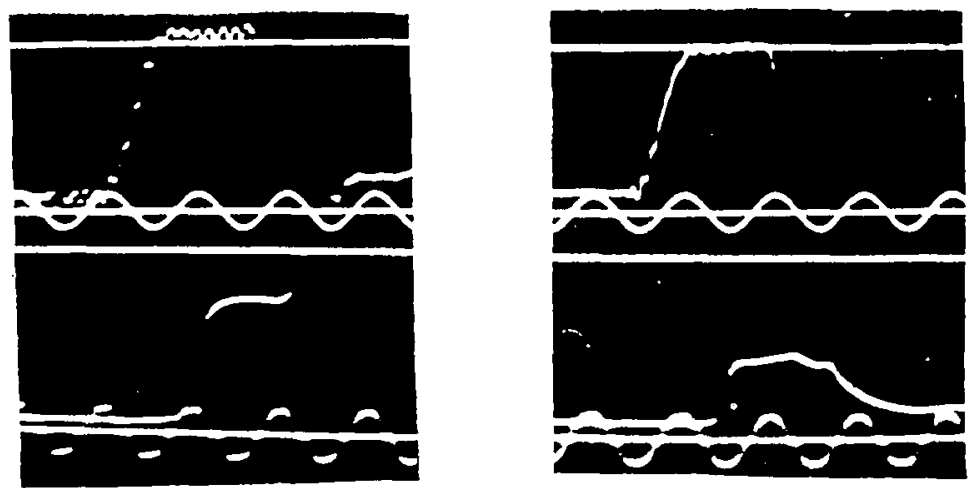

Fig.l

Amplitude values of $\sigma_{x}$ and $\sigma_{y}$ stresses were calculated using unified calibration dependence of $\sigma_{1}$ on relative change of $\Delta R / R$ resistance of gauges

$$
\sigma_{\mathrm{i}}=34.5(\Delta \mathrm{R} / \mathrm{R})+7.5(\Delta \mathrm{R} / \mathrm{R})^{2} \mathrm{GPa}
$$

Plane shock waves were generated in samples by explosive devices with known parameters of shock waves in screens. Duration of stationary flow behind the SW front (duration of rectangular profile $\left.\sigma_{x}\right)$ was equal to $(1-3) \mu s$. This is sufficient for reliable measurement of $\sigma_{x}$ and $\sigma_{y}$ in the stationary regime of flow. Values of $\sigma_{x}$, obtained by experiments, in the limits of measurement error comply with $\sigma_{x}$ values, calculated when solving the task on disintegration of arbitrary break. Results of the experiments are tabulated in Table 1 . Accuracy of $\sigma_{x}$ and $\sigma_{y}$ measurements in one experiment was $\pm 8 \%$ or better. Correctness of $\sigma_{y}$ measurements was confirmed by results of special experiments carried out employing the same scheme with the same gauge design using paraffin, steel, vanadium and ceramics [8].

The following $\sigma_{x}$ and $\sigma_{y}$ values were obtained for paraffin; $\sigma_{x}=0.69 \mathrm{GPa}, \sigma_{y}=0.67 \mathrm{GPa}$, and $\sigma_{\mathrm{r}}=2.31 \mathrm{GPa}, \sigma_{y}=2.24 \mathrm{GPa}$, i.e., the stressed state corresponds to the hydrodynamic state. In the elastic area of deformation of St.3 and 30KhGSA steels [9] the values of Poisson's ratio $v=\sigma_{y} /\left(\sigma_{x}+\sigma_{y}\right)$, calculated basing on measured values of $\sigma_{x}$ and $\sigma_{y}$, agree with the literature values, namely, $v=0.28$ for St. 3 and $v=0.30$ for $30 \mathrm{KhGSA}$. In the elasto-plastic area the experimental data are well described by theoretical dependence

$$
\sigma_{0}=\frac{\sigma_{x}+\sigma_{y}}{2} \pm \frac{\sigma_{x}-\sigma_{y}}{2} \cos 2 \theta
$$

where $\sigma_{\theta}$ - normal stress on a plane oriented at an angle of $\theta$ to the plane of the wave front [9]. Dependence of $Y_{\mathrm{g}}$ on $\sigma_{\mathrm{x}}$, obtained by the interference method in [11], was reproduced for vanadium by the method of primary stresses. Measurements on cast ceramics (where aluminium oxide is the basis) [12] are in agreement with general regularities of ceramics behaviour: high value of the elastic Hugoniot limit and constancy of $Y_{\mathrm{g}}$ in the plastic area. In the elastic area the value of $v$, as for steels, is equal to the value of it under normal conditions. 
It follows from data presented in Table 1 that strong hardening of low-melting metals takes place in shock waves in the investigated range of stresses, where they are in the solid phase. Reasons of this require additional study. One of possible reasons is good compressability of investigated metals: the bulk modulus for them is $\mathrm{K} \cong(36-70) \mathrm{GPa}$ opposite to $\mathrm{K} \cong(100-280) \mathrm{GPa}$ for such typical metals as copper, iron, titanium, molybdenum.

Table 1

Results of $\sigma_{x}$ and $\sigma_{y}$ measurements in low-melting metals.

\begin{tabular}{|c|c|c|c|}
\hline \multirow[t]{2}{*}{ Metal } & \multicolumn{3}{|c|}{ Stresses, GPa } \\
\hline & $\sigma_{x}$ & $\sigma_{y}$ & $Y_{g}$ \\
\hline \multirow{7}{*}{$\begin{array}{l}\text { Magnesium } \\
\rho_{0}=1.74 \mathrm{~g} / \mathrm{cm}^{3}\end{array}$} & 2.35 & 2.0 & 0.35 \\
\hline & 5.45 & 4.65 & 0.80 \\
\hline & 6.30 & 5.55 & 0.75 \\
\hline & 8.98 & 7.82 & 1.16 \\
\hline & 9.30 & 7.95 & 1.35 \\
\hline & 15.30 & 13.85 & 1.45 \\
\hline & 21.30 & 19.60 & 1.70 \\
\hline \multirow{4}{*}{$\begin{array}{l}\text { Cadmium } \\
\rho_{0}=8.64 \mathrm{~g} / \mathrm{cm}^{3}\end{array}$} & 4.83 & 2.80 & 2.03 \\
\hline & 10.15 & 6.00 & 4.15 \\
\hline & 14.35 & 9.0 & 5.35 \\
\hline & 18.70 & 13.75 & 4.95 \\
\hline \multirow{3}{*}{$\begin{array}{l}\text { Bismuth } \\
\rho_{0}=9.81 \mathrm{~g} / \mathrm{cm}^{3}\end{array}$} & 4.13 & 1.64 & 2.47 \\
\hline & 10.55 & 7.25 & 3.30 \\
\hline & 14.30 & 7.30 & 7.0 \\
\hline \multirow{2}{*}{$\begin{array}{l}\text { Zinc } \\
\rho_{0}=7.14 \mathrm{~g} / \mathrm{cm}^{3}\end{array}$} & 4.60 & 3.15 & 1.45 \\
\hline & 16.30 & 10.60 & 5.70 \\
\hline \multirow{2}{*}{$\begin{array}{l}\text { Tin } \\
\rho_{0}=7.28 \mathrm{~g} / \mathrm{cm}^{3}\end{array}$} & 5.53 & 2.57 & 2.96 \\
\hline & 10.80 & 6.25 & 4.55 \\
\hline
\end{tabular}

$\mathrm{Y}_{\mathrm{g}}\left(\sigma_{\mathrm{x}}\right)$ dependence for magnesium along shock adiabat, proposed in [13], is the following:

$$
Y_{g}=Y_{0}\left[\left(1+\beta e_{p}\right)^{m}+\alpha P\right] \cdot\left[1-\frac{\varepsilon_{T}}{\varepsilon_{T}^{n \Omega}}\right]
$$

where $Y_{0}, \beta, m, \alpha$ - are constant, $e_{p}$ - intensity of plastic strains, $\varepsilon_{T}$ - present thermal energy, $\varepsilon_{T^{\mathrm{n}}}^{\mathrm{n}}$ - thermal energy needed for homogenous heating up to the melting temperature, when density is specified. $\varepsilon_{\top}{ }^{n \pi}$ describes experimental data on the ascending branch, where they exist (fig.3). Value of $\varepsilon_{\mathrm{T}}^{\text {na }}$ from (1) is calculated using Lindeman's law with function of Gruneisen's coefficient.

$$
\begin{gathered}
\gamma_{p}=\gamma_{\infty}+\frac{\gamma_{0}-\gamma_{\infty}}{\delta^{M}} \\
\varepsilon_{T}^{n n}=\varepsilon_{T_{0}}^{n n}\left(\delta_{n n} / \delta_{0 n n}\right)^{2\left(\gamma_{\infty}-1 / 3\right)}, \exp \left[\frac{2\left(\gamma_{0}-\gamma_{\infty}\right)}{M\left(\delta_{0 n n}\right)^{M}}-\frac{2\left(\gamma_{0}-\gamma_{\infty}\right)}{M\left(\delta_{0 n n}\right)^{M}}\right]
\end{gathered}
$$

Term $Y_{0}\left(1+\beta e_{p}\right)^{m}$ is limited by $Y_{\max }$ value.

Parameters of determining magnesium equation are presented in Table 2. 
Parameters of determining magnesium equation

\begin{tabular}{|l|c|c|c|c|c|c|c|}
\hline Parameters & $\gamma_{0}$ & $\gamma_{\infty}$ & $\mathrm{M}$ & $\mathrm{Y}_{0}, \mathrm{GPa}$ & $\mathrm{Y}_{\max }, \mathrm{GPa}$ & $\beta$ & $\mathrm{m}$ \\
\hline Value & 1.6 & 0.7 & 2.3 & 0.19 & 0.48 & 317 & 0.50 \\
\hline
\end{tabular}

\begin{tabular}{|l|c|c|c|c|c|}
\hline & $\alpha, \mathrm{GPa}^{-1}$ & $\rho_{0}^{n n}, g / c$ मे $^{3}$ & $T_{0}^{n n o}, K^{\prime}$ & $\varepsilon_{0}^{n n}, j / g$ & \\
\hline & 0.60 & 1.62 & 922 & 963 & \\
\hline
\end{tabular}

Results of performed investigations and analysis of the problem state in the review work [4] show that investigations of shear strengths of low-melting metals were carried out on the ascending branch of $Y_{g}\left(\sigma_{x}\right)$ dependence. That is why it is interesting from practical and scientific points of view to expand investigations in the area close to the melting state on shock wave. It can be realized in practice for low-melting metals.

\section{REFERENCE}

[1] Альтшулер, С.Б.Кормер, М.И.Бражник и др.,ЖЭТФ, 1960, 38, вып. 4, с.1061-1073.

[2] J.Assay. L.Chhabildas.,J.Appl.Phys., 1980, 51, N 9, p.4774-4783.

[3] Z.Rosenberg, Y.Partom, D.Yaziv.,Ibid, 1984, 56, N 1, p.143-146.

[4] D.Bernstein, C.Codfrey, A.Klein et al. Research on manganin pressure transducers//Behaviour of Dense Media under High Dynamic Pressures. N.-Y.; Gordon and Breach, 1968, p.461.

[5] Ю.В.Батьков, С.А.Новиков, Л.М.Синицына и др., Проблемы прочности, 1981, N5, с.56-59.

[6] D.Streinberg, S.Cochran, M.Guinom., J.Appl.Phys., 1980, 51, N3, p.1498-1504.

[7] Л.В.Альтшулер, Б.С.Чекин., ПМТФ, 1987, N6, с.119-128.

[8] Ю.В.Батьков, А.Б.Глушак, Б.Л.Гушак, С.А.Новиков, Н.Д.Фишман., ФГВ, 1995,т.31, N5, c.114-120.

[9] Ю.В.Батьков, Б.Л.Глушак, С.А.Новиков.,ФГВ, 1989, 25, N5, с.126-132.

[10] Yu.V.Bat'kov, S.A.Novikov, N.D.Fishman., Shear stresses in polymers under shock compression.//Shock Compression of Condensed Metter, 1995.,p.577-580.

[11] L.C.Chhabildas and C.R.Hills. Dynamic shock studies of vanadium//Metallurical Application of Shock-Wave and High-Strain-Rate Phenomena/Ed.L.E.Murr and al. N.Y.Basel, 1986.

[12] Yu.Bat'kov, S.A.Novikov, L.M.Timonin. Strenth behind shock wave from in ceramic materials based on alumina//High Energy Rate Fabrication. Ljubliana, Yugoslavia, 1989, p.256-262.

[13] Б.Л.Глушак, С.А.Новиков, Ю.В.Батьков.,ФГВ, 1992, 28, N1, с.84-88.

[14] Ю.В.Батьков, Б.Л.Глушак, С.А.Новиков. Сопротивление материалов пластической деформации при высокоскоростном деформировании в ударных волнах (Обзор)//М.:ЦНИИатоминформ, 1990. 